\title{
The Making of Abiezer Coppe
}

\author{
by ARIEL HESSAYON \\ Goldsmiths, University of London \\ E-mail:a.hessayon@gold.ac.uk
}

This article seeks to uncover the origins of the 'Ranters' by examining Abiezer Coppe's early life and social network. It suggests that Coppe's background, experiences and milieu-particularly his Baptist phase and the associations he made during this period - are crucial to appreciate the genesis of the 'Ranters'. As such it should be regarded as a further contribution towards the growing consensus that the origins of 'radicalism' in the English Revolution are to be located in the religion of the 'hotter sort' of Protestants lower down the social scale.

'Some said He is a good man; others said, Nay but he is mad, and hath a devil. He is a wine-bibber, a glutton and a drunkard; a friend of publicans and harlots. But wisdom is justified of her children.'

biezer Coppe's epigraph to A remonstrance of the sincere and zealous
Protestation of ABIEZER COPPE (printed by James Cottrell in I65I) is
a revealing choice of words for a man who, at the time of writing, had
'patiently, cheerfully, and silently sustained (through the malice, ignorance
mistake, and blinde zeal of Informers) a tedious twelve-months imprisonment
in the common Gaols of Warwick, Coventry, and that most infamous Gaol
of Newgate'. This epigraph is a reworking of two verses in Matthew's

$\mathrm{BL}=$ British Library; TNA $=$ The National Archives; WORO $=$ Worcestershire Record Office; WRO = Warwickshire Record Office

This article originates in my entry on Abiezer Coppe for the $O D N B$. A version was read at the seminar for Early Modern British History at the Institute of Historical Research. I would like to thank the participants for their helpful comments and suggestions. In addition, I have profited from the advice of Justin Champion, David Como, J. Colin Davis, J. R. L. Highfield, Nicholas McDowell, John Morrill, William Poole and Nigel Smith. I am also grateful to the Leathersellers' Company for permission to consult their records. Though Coppe sometimes glosses scriptural phrases he does not provide many of his biblical allusions. I have therefore thought it helpful to supply these and other references in brackets. I alone am responsible for any mistakes or shortcomings.

1 Abiezer Coppe, A remonstrance of the sincere and zealous Protestation of Abiezer Coppe, London I65I (Wing C.6089), I. 
Gospel: 'For John came neither eating nor drinking, and they say, He hath a devil. The Son of man came eating and drinking, and they say, Behold a man gluttonous, and a winebibber, a friend of publicans and sinners. But wisdom is justified of her children' (Matthew xi.I8-I9). ${ }^{2}$ The allusion is a significant one. Like his 'fore-runner' (Hebrews vi. 20) before him, who was rejected by the unbaptised Pharisees and lawyers, Coppe believed that he had been cried up 'by all sorts even of the most religious and righteous men', for 'the worst of sinners, the vilest of persons'; for a 'Blasphemer' and a 'Devil'. Pitying the 'Malice in some', the 'Weakness, Ignorance, and Mistake in others', Coppe resolved with the help of 'the Omnipotent, Omnipresent JEHOVAH' to 'enlarge' himself, to 'give an account' of himself 'in reference' to 'those Various Dispensations past and present' (cf. Ephesians iii. 2) that he had been 'led into and thorow'. This 'ensuing Remonstrance Vindication and Attestation' would remove 'stumbling-blocks' (cf. I Corinithians. i. 23), clear up 'mistakes' and wipe away 'aspersions' that had been cast upon him. For he had been 'so covered with a cloud' (cf. Lamentations ii. I), 'that not one amongst a thousand' knew him. ${ }^{3}$

Coppe's name, previously associated with Anabaptism and enthusiasm, has latterly become synonymous with the 'Ranters' and by extension the heated dispute surrounding their existence. ${ }^{4}$ Using a number of sources in

${ }^{2}$ Cf. Luke vii.33-5.

3 Coppe, Remonstrance, title page, $\mathrm{I}-2$.

${ }^{4}$ Norman Cohn, The pursuit of the millennium, London 1957, 315-72; J. F. McGregor, 'The Ranters: a study in the free spirit in English sectarian religion, I649-I660', unpubl. BLitt. diss. Oxford i968; A. L. Morton, The world of the Ranters: religious radicalism in the English Revolution, London I970, 70-II4; G. F. Ellens, 'The Ranters ranting: reflections on a ranting counter culture', Church History xl (I97I), 9I-I07; Christopher Hill, The world turned upside down: radical ideas during the English Revolution (1972), Harmondsworth I984 edn, I97-230; J. F. McGregor, 'Ranterism and the development of early Quakerism', Fournal of Religious History ix (1977), 349-63; J. F. McGregor, 'Seekers and Ranters', in J. F. McGregor and B. Reay (eds), Radical religion in the English Revolution, Oxford 1984, I29-39; J. Colin Davis, Fear, myth and history: the Ranters and the historians, Cambridge 1986; Abiezer Coppe: selected writings, ed. Andrew Hopton, London 1987; Jerome Friedman, Blasphemy, immorality, and anarchy: the Ranters and the English Revolution, Athens, $\mathrm{OH}$ i987; Nigel Smith, Perfection proclaimed: language and literature in English Radical religion, I640-I660, Oxford I989; C. Hill, 'Abolishing the Ranters', in his A nation of change and novelty, London I990, I52-94; J. C. Davis, 'Fear, myth and furore: reappraising the Ranters', Past \& Present cxxix (1990), 79-I03; B. Nelson, 'The Ranters and the limits of language', in James Holstun (ed.), Pamphlet wars: prose in the English Revolution, London 1992, 6o-75; Thomas Corns, Uncloistered virtue: English political literature, I640-I66o, Oxford I992, I74-93; J. F. McGregor, B. Capp, N. Smith, B. J. Gibbons and J. C. Davis, 'Debate: fear, myth and furore: reappraising the Ranters', Past \& Present cxl (I993), I55-2 IO ; O. Nicastro, 'Scrittura, mistero e storia nel Ranter Abiezer Coppe (16r9-1672)', in Guido Canziani and Yves Charles Zarka (eds), L'interpretazione nei secoli XVI e XVII, Milan I993, 587-625; Clement Hawes, Mania and literary style: the rhetoric of enthusiasm from the Ranters to Christopher Smart, Cambridge 1996, 34-41, 77-97; N. McDowell, 'A Ranter reconsidered: Abiezer Coppe and Civil War stereotypes', Seventeenth Century xii (I997), I73-205; R. Kenny, "In these last dayes": the strange work of Abiezer Coppe', Seventeenth Century xiii (1998), I56-84; Noam Flinker, The Song of Songs in English Renaissance literature: kisses of their mouths, Woodbridge 2000, 120-39; 
manuscript and print unknown to or untapped by previous scholars, this article seeks to uncover the origins of the 'Ranters' by examining Coppe's early life and social network. This article is also a contribution towards the growing consensus that the origins of 'radicalism' in the English Revolution are to be located in the religion of the 'hotter sort' of Protestants lower down the social scale. As all researchers are only too well aware, there is a real problem of what the evidence does and does not say - and how far one can push it to make a point. What can be said with certainty I have said. What cannot I have indicated. The issue, of course, is whether the necessary use of conditional statements weakens this-or any-argument. If one were arguing about the relative merits of competing fictions this would probably not matter. But for most historians who still believe in a recoverable past - however partial - it still does. Therefore what is at stake here is a vision of an aspect of that past that competes with other interpretations. It is for the reader to privilege the most persuasive.

In a pioneering piece J. D. Alsop declared that 'the image of an alienated Gerrard Winstanley, from birth a partaker of confrontational, aggressive religious zeal, is wholly mythical ${ }^{\prime} .^{5}$ Equally, in establishing so far as is possible the main features of Coppe's life before he was 'shewn a more excellent way', the concern is not to read backwards from a preferred version of the many disputed representations now available of him, ${ }^{6}$ but rather to read forwards to see how the early life and its contexts inform the later. Accordingly, it will be suggested that Coppe's ancestry, his family's agrarian background, his father's social standing and religious opinions, his own troubled adolescence, schooling at Warwick, exposure to vehemently anti-Catholic, anti-Arminian and anti-Socinian opinions at Oxford, entry and promotion within a circle of godly clergy supported by Lord Brooke, appointment as minister to a Parliamentary troop, adoption of adult baptism, association with prominent and highly organised London-based Baptists, and the doctrine of free grace were all formative experiences prior to the profound transformation that he underwent in his twenty-eighth year: an experience that he came to represent as a spiritual passage from death to life. Moreover, the ways in which Coppe was shaped are essential for understanding his most developed ideas, the modes of their expression and their impact. Some events may be considered more significant. Coppe's Baptist phase and the associations he

David Loewenstein, Representing revolution in Milton and his contemporaries, Cambridge 200I, 93-II5; Nicholas McDowell, The English radical imagination: culture, religion, and revolution, I630-I660, Oxford 2003, 89-I36; Mario Caricchio, Religione, politica e commercio di libri nella rivoluzione inglese: gli autori di Giles Calvert, I645-I653, Genoa 2003, I64-200; N. McDowell, 'Abiezer Coppe, Horace, and the dormouse', Notes and Queries liii (2006), I66-8.

${ }^{5} \mathrm{~J}$. D. Alsop, 'A high road to radicalism? Gerrard Winstanley's youth', Seventeenth Century ix (I994), I I-24 at p. I4.

${ }_{6}$ Abiezer Coppe, Copp's return to the wayes of truth, London I65I (Wing C.6ogo), sig. A2r-3. 
made during this period, for example, are crucial to an appreciation of what came next. The narrative voice has been adopted because it lends coherence to the original material. Nor has this approach been unduly influenced by the prevailing historiography - itself largely a reflection of and engagement with early modern discourses on perceived heresy. In short, while much of what I have to say is implicit, I hope that readers will find my argument easy to follow: Coppe's milieu before I648 reveals the genesis of the 'Ranters'.

\section{'Tea yea, nay, nay'}

Abiezer Coppe was born, according to his nativity, at Warwick on Sunday, 30 May I6I9 at 3.41 p.m. ${ }^{7}$ He was baptised on Tuesday i June in the parish of St Mary, Warwick, the eldest known child of Walter Coppe (I593-fl.i667). ${ }^{8}$ His father was the youngest child of Thomas Coppe (d.I628?), yeoman of Beausale in the parish of Hatton, Warwickshire, and Isabell ( $f$.1624), daughter of Richard Gunne (d.I59I), of Ilmington, Warwickshire. ${ }^{9}$ There is some evidence that the Coppes of Beausale were modest farmers. In 1545 a John Coppe had a lease of a messuage and a close called 'Ruytons Bury' or 'Rounde Table' in Beausale, while a Thomas Coppe, husbandman, swore in the court of Exchequer in 1597 that for over forty years he had worked closes called 'Will Richard' and 'Dowry' in Beausale. ${ }^{10}$ Other members of the Coppe family were charged in the court of Star Chamber in I6 Io with killing a buck in Wedgnock Park, which lay to the north of Warwick. ${ }^{11}$

Thomas Coppe and Isabell Gunne were married at Hatton on 28 February $1576 .{ }^{12}$ Little is known of their offspring. Their eldest son Anthony Coppe (I576-I654), yeoman of Honiley, Warwickshire, bequeathed his lease of a house and land in Honiley for the use of his brother Walter's children as well as giving them 20s. each. He could sign his own name. ${ }^{13}$ Three of Thomas and Isabell's progeny, Johan, Thomas and William, were married at Hatton. ${ }^{14}$ Thomas Coppe (I582-I639) or his father paid a yearly rent of two fat pigs and one fat goose in $\mathrm{I} 624$ for the pasture and woods known as 'Round Table'. ${ }^{15}$ He was a farmer who grew wheat, rye, oats, peas and barley and kept cows, horses, sheep, pigs and geese. His estate was appraised at II $3 l$. I6s. $4 d .^{\mathbf{1 6}}$ William Coppe (I589-fl.i653?) may be the shoemaker of that

7 Ibid. sig. B2; John Gadbury, Collectio geniturarum, London i662 (Wing G.8o), Io6.

${ }^{8}$ WRO, PG 3534. $\quad{ }^{9}$ WRO, DR 477/r; WORC (County Hall), oo87, nos 50, 62.

10 TNA, LR 2/I8I, fo. I96v; deposition of Thomas Coppe of Beausale (I597), E I34/38, 39 Eliz/Mich8.

11 TNA, STAC $8 /$ I $_{58 / 26 .}$

12 Warwickshire parish registers, ed. W. P. M. Phillimore, J. L. Whitfield and J. H. Bloom, London I9o6, iii.I3o; cf. baptism of 'Anthonie filius Thome Coppe', 2 Sept. 1576, WRO, DR 477 / . 13 TNA, Prob ir/24I, fos 39iv-392r.

14 Warwickshire parish registers, iii. I32. ${ }^{15} \mathrm{WRO}, \mathrm{CR}$ I6I8/W I5/20; CR 2758/I, fo. Iogr.

16 WORO (County Hall), oo87, no. 44 . 
name who in 1636 was granted a lease of land in Hatton. ${ }^{17} \mathrm{He}$ emigrated to New England, perhaps settling at Boston with his family. ${ }^{18}$ Walter Coppe had several children; Abiezer, Thomas (buried a few days after baptism), Anna (b.I622), James (b.I623), Sarah (I629-34) and Mary (b.I633) ${ }^{\mathbf{1 9}}$ In I624 he was given $7 s$. $6 d$. for clothing a poor boy by the feoffees in trust of the Warwick gentleman Thomas Oken's charity. ${ }^{20}$ Though Walter Coppe was never assessed for a Parliamentary subsidy in the borough of Warwick before the outbreak of Civil War it seems that he was not a poor man. ${ }^{21} \mathrm{He}$ could sign his own name, was described as a tailor and witnessed the will of a Warwick fellmonger, indicating his commercial links with the town's tanning industry. ${ }^{22}$ On i9 June 1646 he presented a bill for $6 l$. I8s. disbursed in helping the Parliamentary war effort, including money spent quartering soldiers at his home in Jury Street ward. ${ }^{23}$ His wife, and perhaps the mother of his children, was buried at St Mary, Warwick, on I I August I658. ${ }^{24}$ After the Restoration Walter Coppe secured a seat in the middle aisle of his parish church and between I662 and I667 was rated at three hearths in Jury Street ward. $^{25}$

St Mary, Warwick, appears to have had little by way of an established tradition of nonconformity before the outbreak of Civil War. A surviving visitation book records breaches of canon law for which parishioners were presented: offences include gathering peas upon the Sabbath. ${ }^{26}$ In the episcopal returns of i669, however, an Independent conventicle was reported and some Quakers and Baptists said to be in the parish. ${ }^{27}$ In 1674 the churchwardens presented an Independent, a Baptist and two Quakers, while in the ecclesiastical survey of 1676 known as the Compton Census ninety-six communicants were listed as Nonconformists. ${ }^{28}$ Furthermore, two men were presented in 1684 for holding conventicles and a further nine parishioners (seven men and two women) were presented for not coming to church. Neighbouring St Nicholas also had its share of Independents, Baptists and Quakers, as well as a reputed Fifth

\footnotetext{
17 WRO, CR I6I8/W 2i/6, fo. I37.

18 Prob i / 24I, fo. 39Iv; cf. New world immigrants, ed. Michael Tepper, Baltimore i980, i. 49.

19 WRO, DR $477 / 34$.

${ }^{21} \mathrm{E}$ I79/193/274, 280, 301; E I79/259/i; E I79/ı94/308, 310.

22 Shakespeare Birthplace Trust Records Office, ER 2/450; Prob i / 278, fos 28v-29r.

23 TNA, SP 28/184 (no piece number, no foliation).

${ }^{24}$ WRO, DR $447 / \mathrm{I}$; DR I33/r6 (no foliation).

${ }^{25}$ WRO, DR I33/i6 (no foliation); E I79/259/9, fo. 205v; i79/259/io, mem. I3v.

${ }^{26}$ WORO (St Helen's), BA 276o. 802, fos 47v, 58r, 58v, 63r, 97v, io3r.

27 Original records of early Nonconformity under persecution and indulgence, ed. G. Lyon Turner, London igi i, i. I49.

28 Churchwardens' presentments, 23 Sept. I674, WORO (St Helen's), BA 2289. 807/2 I (ii) St Mary, Warwick; The Compton Census of 1676 : a critical edition, ed. Anne Whiteman, Oxford I986, I86.
} 
Monarchist. ${ }^{29}$ This manifest dissent may have stemmed from the godliness of an earlier era, but it is not easy to establish a link. Likewise, it is difficult to ascertain the religious beliefs of Abiezer Coppe's grandfather and uncles. On 7 September i624 Thomas Coppe the elder drew up his will. After the customary preliminaries the preamble continued 'First I com[m]itte, \& com[m]ende my soule to Almightie God hopinge \& trustinge to be saued by the mercie of Jesus Christ. ${ }^{30}$ The notary was one Richard Warde and it is likely that the form of words that he used was derived from a precedent book. Though it cannot be read as an expression of personal piety but only as Thomas Coppe's assumed consent to the manner in which he bequeathed the most valuable possession in his custody, it is noteworthy that this formula was not characteristic of orthodox Calvinist doctrine. Similarly, the phraseology used in Anthony Coppe's will made on I6 January i654 contains no reference to everlasting life in the kingdom of heaven among the elect: 'I bequeath my soule into the hands of my maker and my body to the earth from whence it was taken beinge assured by the merritts of Jesus Christ my Redeemer to receive a ioyfull resurrection at the last day. ${ }^{31}$

Walter Coppe appears to have died intestate. Even so, on 26 December I666 he witnessed a Warwick widow give a receipt to the guardian of one Lovisgod Gregory. ${ }^{32}$ This name hints at Walter Coppe's place within a godly network, a suggestion reinforced by his eldest known child's name - Abiezer. Derived from the Hebrew Bible and meaning help of the father, this was a very rare seventeenth-century name though one of evident significance to its bearer. For Abiezer Coppe would later spell his name in Hebrew characters and translate it into Latin as 'AUXILIUM PATRIS' ${ }^{33}$ Then there is Abiezer's own account.

If his later confession is to be believed, Abiezer Coppe's youth was marked by a godly litany of zealous devotion: fervent prayer 'by heart' at evening and midnight, daily bible-reading and memorising 'much of the Scripture', frequent and 'most secret' fasting and abasement before God: 'Tears were my drink: dust and ashes my meat [cf. Hebrews v. 7]. And Sack-cloth my clothing [cf. Isaiah xxii. I2]. Zeal, Devotion, and exceeding strictness of life and conversation, my life. ${ }^{34}$ At the age of thirteen he began to 'take and keep' a daily register of his sins, setting them down in a book. To prevent his tongue from speaking sinful words he bridled his mouth (Psalm xxxix.I), writing upon scrolls of parchment the inscription ' $Y e a$ yea, nay, nay'

${ }^{29}$ Churchwardens' presentments, 4 June i684, WORO (St Helen's), BA 2289. 807/2I (ii), St Mary, Warwick; churchwardens' presentments, 23 Sept. I674, ibid. (iii), St Nicholas, Warwick.

${ }^{31}$ Prob ir/24I, fo. 39iv. $\quad{ }^{32}$ Shakespeare Birthplace Trust, DR io/I754.

${ }^{33}$ Abiezer Coppe, Some sweet sips, of some spirituall wine, London I649 (Wing C.6o93), title-page; A fiery flying roll, London I649 (Wing C.6o87), title page.

34 Idem, Copp's return, 3 . 
(Matt. v. 37), which he sewed about his wrists. ${ }^{35}$ As a native of Warwick, Coppe was able to attend the town's free school, where he was doubtless instructed in the 'king's grammar'. Conceived by William Lily and John Colet it was adopted as the standard Latin grammar of the period and was a text that Coppe would later parody. At the age of fifteen it appears that Coppe began taking lessons with the recently appointed Master of Warwick School, Thomas Dugard (1608-83). Educated at Sidney Sussex College, Cambridge, the 'godly' Dugard reportedly instilled instruction both with his 'lips and life'. ${ }^{36}$ In his diary entry for 18 October I6 34 he noted laconically that Coppe and two other boys had received tuition from a Greek New Testament and Homer; another lad was taught from Aesop's fables. Further entries in the diary indicate Coppe's progress, notably a reference on 6 December I634 to Dugard's after-dinner reading of several sacred epigrams in Latin recently published at Cambridge by Richard Crashaw. In addition, Dugard gave Coppe books and conferred with his father in the chapel of Warwick Castle. ${ }^{37}$ By the age of sixteen Coppe would have received his first communion, and this also seems to have been about the age at which church attendance became compulsory. St Mary was provided with gifts for sermons and besides the vicar Thomas Hall, among those who preached there were Dugard and his friend the moderate Puritan John Bryan (d.I676). Warwick also had a weekly lecture preached in rotation by local ministers and it may have been at one of these gatherings that Coppe apparently heard a divine assert that the thought of adultery was worse than committing the act. $^{38}$

Some of Dugard's pupils went on to attend university such as John Roe (Emmanuel College, Cambridge), John Pilkington (Magdalen Hall, Oxford), William Sheene (Magdalen Hall, Oxford) and John Murcot (Merton College, Oxford) ${ }^{39}$ It may therefore have been through Dugard's connections that Coppe secured a place at Oxford. At an unknown date he was admitted at All Souls. He subscribed to the Thirty-Nine Articles - one of two known examples of his hand - and matriculated as a plebeian on 20 May ${ }_{16} 6{ }_{3}{ }^{40}$ Within a few weeks Coppe returned to Warwick, visiting Dugard on

35 Ibid. 2.

36 'Moses in the mount', in Several works of Mr. Iohn Murcot, London I657 (Wing M.3083), 3.

${ }^{37}$ BL, ms Add. 23, I46, fos 3Iv, 32v, 33r, 33v, 38r, 40v, 4Iv; A. Hughes, 'Thomas Dugard and his circle in the I63os: a "Parliamentary-Puritan" connexion?', $H f$ xxix (I986), $77 \mathrm{I}-93$ at p. 779 .

${ }_{38}$ Ecclesiastical terriers of Warwickshire parishes, ed. D. M. Barratt (Dugdale Society xxvii, 197I), ii. Ioo; John Bryan, The vertvovs davghter, London i640 (STC 3956); Coppe, Copp's return, 20.

39 John Venn and J. Venn (eds), Alumni cantabrigienses from the earliest times to I75I, Cambridge 1922-7, iii. 492; Joseph Foster (ed.), Alumni oxonienses: the members of the University of Oxford, I500-I7I4, Oxford I89I-2, iii. I046, II64; iv. I342.

40 Bodleian Library, Oxford, O.U.A., S.P. 2, fo. 68r; O.U.A. S.P. 39, (no foliation), 20 May I636. 
29 June; maybe he watched Dugard deliver an oration in Latin welcoming Charles I as an Augustus when the king visited Warwick on 20 August. ${ }^{41}$

Coppe probably came into residence during the following term, no doubt to save money. His name, however, is absent from battels receipts, confirming the suggestion of the antiquary Anthony Wood (I632-95) that he was a servitor. ${ }^{42}$ As such Coppe may have served meals to wealthier students and perhaps carried out domestic duties like bed-making, firelighting, sweeping and buying provisions. It is not known for whom Coppe acted as servitor or who his tutor was, but given his poverty the Warden Gilbert Sheldon (I598-I677) doubtless left his supervision to one of the younger men, perhaps Henry Barker of Berkshire, John Prestwich of Lancashire, or even Jeremy Taylor (1613-67), who had been appointed a permanent Fellow on I4 January I636 and was to become chaplain to William Laud (I573-I645), archbishop of Canterbury and Chancellor of the University of Oxford.

Wood thought that Coppe continued at All Souls 'for a short time' before becoming one of the postmasters of Merton College. ${ }^{43}$ Postmasters formed the bulk of the student body at that college, having been established in I38o by John Willyot. According to their founder they were to be chosen by the Warden, the Principal of the Postmasters and three senior Fellows. At the time of Coppe's migration the Warden was Sir Nathaniel Brent (I573/ 74-I652), a Warwickshire man and church lawyer subsequently censured by Wood for 'minding wealth and the settling a family more than generous actions'. ${ }^{44}$ Francis Cheynell (I608-65) was the Principal of the Postmasters for one year from i August I6 $36 .^{45} \mathrm{He}$ caused controversy in October I636 with a fast sermon that displeased both the town and university, and afterwards preached against Arminianism and Socinianism, revealing himself as 'a presbyterian, and an enemy to the bishops and ceremonies of the church' ${ }^{46}$ Among the Fellows of Merton were Edward Corbet $(c .1602-58)$ and Edward Hinton (c.1609-78). Remembered as a 'Pious, Sound, and Learned' tutor and a 'real Saint on earth' Corbet, like Cheynell, was to become an outspoken critic of Laud's innovations, refusing to bow towards the communion table in the University Church at common prayers. He preached a fast sermon before the House of Commons in December I642 and later married Brent's daughter. ${ }^{47}$ Hinton was to denounce popery,

${ }^{41}$ BL, MS Add. 23,I46, fo. 53v; Thomas Dugard, Philobasileus, London r664 (Wing D. $2463 \mathrm{~A}),{ }^{-1}{ }^{-1} 6$.

${ }_{22}$ Bodl. Lib., ms D.D. All Souls Coll. b.78; Anthony Wood Athenae oxonienses, ed. Philip Bliss, London I8I3-20, iii, col. 959 .

${ }^{44}$ Ibid. ii, col. $3^{1} 6$.

${ }^{43}$ Wood, Athenae oxonienses, iii, col. 959.

Merton College, Oxford, MCR Reg.r.3, p. 324

${ }^{46}$ Nottingham University Library, Ms Cl. c.75; Wood, Athenae oxonienses, iii, col. 703.

47 Nicholas Clagett, The abuse of Gods grace, Oxford 1659 (Wing C.4368), sig. A2; CSPD, ${ }_{1} 638-39,46,68 ; C S P D,{ }_{1} 639-40,509 ; C S P D,{ }_{1} 640-4 I, 325$; The works of the most reverend father in God, William Laud, ed. William Scott and James Bliss, Oxford ı847-6o, iv. 220-I. 
Arminianism and Socinianism, turning into an avowed Presbyterian. ${ }^{48}$ It seems that Brent and Cheynell, possibly together with Corbet, Hinton and another man, sponsored Coppe's nomination.

As a postmaster, Coppe was entitled to come into hall for supper at the same time as the Fellows. His tutor, as Wood correctly supposed, was Ralph Button (c.1612-80). ${ }^{49}$ Elected a Fellow of the college in 1633 on the recommendation of Dr John Prideaux (I578-I650), Rector of Exeter College and a vociferous opponent of Arminianism, Catholicism and Socinianism, Button spent a year on probation before being admitted into the society on io October i636. Although Richard Baxter considered him a 'most humble' worthy, godly man of 'a plain, sincere Heart', he was, in Wood's estimation, a 'snivling', 'rigid presbyterian'. Yet Button was also - as Baxter affirmed and Wood conceded - an excellent scholar and a noted tutor. ${ }^{\mathbf{5}}{ }^{2}$ Like another Fellow of Merton, Henry Jacob (c.I6o8- $\left.{ }^{2}\right)$, who praised Charles I with poems in Greek and Hebrew, Button was to contribute Hebrew verses to collections issued by the university in honour of Charles I, Oliver Cromwell and the restored Charles II. ${ }^{51}$ This is significant because Button could have taught Coppe Hebrew. Moreover, Button was to amass a substantial library and may have loaned Coppe books-even if it is impracticable to establish titles in his possession at that time from a catalogue made after his death. ${ }^{52}$ Button's duties most likely involved overseeing Coppe's education, finances, religious devotions and conduct. Indeed, despite his inexperience, Button's influence upon Coppe was probably considerable. This 'faithful and religious' tutor afterwards supervised Samuel Stone (c.I62 I-fl.1638) of Dorset ${ }^{53}$ Zachary Bogan (I625-59) of Devon, who became a renowned orientalist and classical scholar; ${ }^{54}$ John Murcot (c.I625-54) of Warwick, a future Independent minister averse to swearing and Socinianism $;{ }^{55}$ and Edward Wood (d.I655) of Oxford, an elder brother of the antiquary, later Fellow of Merton and Junior Proctor, administered to on

${ }^{48}$ Edward Hinton, The vanity of self-boasters, London I643 (Wing H.2066), I-4, 6-7, 28-9.

${ }^{49}$ Wood, Athenae oxonienses, iii, col. 959.

50 Richard Baxter, Reliquiae Baxterianiae, ed. Matthew Sylvester, I696 (Wing B.I370), pt III, pp. 36, 96; Wood, Athenae oxonienses, iii, cols. 307, 325, 381, and Wood, Fasti oxonienses, ed. Philip Bliss, London I820, ii, col. I58.

${ }^{51}$ Coronae Caroline quadratura, Oxford 1636 (STC I9036), sig. aaaa2 ${ }^{\mathrm{v}}$; Evcharistica oxoniensia, Oxford I64I (Wing O.883), sig. Dv-2; Musarum oxoniensivm, Oxford I654 (Wing O.902), 6; Britannia rediviva, Oxford I66o (Wing O.863), no pagination.

${ }^{52}$ Catalogus librorum bibliothecis selectissimis doctissimorum virorum viz. D. Radulphi Button, London i68I (Wing B.634I).

53 Foster, Alumni oxonienses, iv. I428; Wood, Athenae oxonienses, iii, col. 54 .

${ }^{54}$ Foster, Alumni oxonienses, i. I44; Wood, Athenae oxonienses, iii, col. 476.

${ }^{55}$ Foster, Alumni oxonienses, iii. I046; Wood, Athenae oxonienses, iii, col. 38I; 'Moses in the mount', 4 . 
his deathbed by Button. ${ }^{56}$ Such an environment conflicts with Anthony Wood's account of Coppe's time at Merton:

being naturally vitious, all lectures or examples could not reform him, or make him live like a Christian. And it was then notoriously known, that he would several times entertain for one night, or more, a wanton huswife in his chamber (under that called Oxoniam quare, as I have heard) in the little or old quadrangle, to whom carrying several times meat, at the hour of refection, he would make answer, when being asked by the way what he would do with it, that 'it was a bit for his cat'. ${ }^{57}$

Undergraduate drinking, whoring, gambling and fighting were a concern to parents and authorities alike (in the i63os there were about 300 alehouses in Oxford), but Wood's depiction of Coppe can almost certainly be dismissed as salacious gossip. In fact the astrologer John Gadbury (I627-1704) extolled Coppe's acumen and prodigious memory, claiming that while he was at University 'few of his years were able to equal him' ${ }^{58}$

On Good Friday, 23 March i638, Dugard wrote to Coppe, presumably while his former pupil was still at Oxford. ${ }^{59}$ How long Coppe remained at Merton is unknown. Perhaps he was still there when Laud issued a series of articles to be answered at a formal visitation. One result was an elaborate code of statutes approved on I3 October I638 which stipulated, among other things, that postmasters were to receive their commons free on Fridays and Saturdays, that members of the foundation were to attend chapel services in surplices and hoods on all Sundays and feast-days, that Fellows and postmasters were to walk about in modest, clerical dress and not curl their hair and that all conversation within the college was to be in Latin. ${ }^{60}$ It is impossible to say what effect these reforms had upon Coppe because financial pressures appear to have forced him to leave the university without taking a degree. ${ }^{61}$

Coppe returned to Warwick with his ties to Dugard intact and his eyes no doubt set on the ministry. Dugard recorded that his former protégé, though probably unlicensed, was permitted to preach on Palm Sunday, I8 April I64I, and at five Tuesday lectures between 27 April and 7 December I64I. ${ }^{62}$ Through Dugard Coppe may have met with Robert Greville (г6o7-43), second Baron Brooke, whose seat was at Warwick Castle and who would die fighting for Parliament in the Civil War. It is also possible that Coppe was introduced to Brooke's chaplains, Simeon Ashe (d.I662), an enemy of Laudianism, and Peter Sterry (I6I3-72), a Cambridge Platonist who

${ }^{56}$ Foster, Alumni oxonienses, iv. I670; The life and rimes of Anthony Wood, antiquary, of Oxford, I632-I695, ed. Andrew Clark (Oxford Historical Society, xix, xxi, xxvi, xxx, xl, I89I-I90o), i. 52,197 .

57 Wood, Athenae oxonienses, iii, cols 959-6o.
58 Gadbury, Collectio geniturarum, Io6.
59 BL, ms Add. $23, \mathrm{I} 46$, fo. $73 \mathrm{v}$.
${ }^{60}$ Merton College, MCR Reg.I.3, p. 335.
61 Bodl. Lib., O.U.A. Nep/Supra Q; MS Wood F.r4; Wood, Athenae oxonienses, iii, col. 960.
${ }^{62}$ BL, ms Add. 23, I46, fos 92v, 93r, 94v, 96r, 96v, 97r, Ioov. 
afterwards delivered sermons before the House of Commons. In addition, Samuel Fisher (d.I665), the one-time Baptist and later Quaker controversialist, claimed that he knew Coppe when he was 'in his standing in the Church of England', observing that 'he had some bounds from conscience to his corruption'. ${ }^{63}$ Fisher was sometime chaplain to Sir Arthur Hesilrige (I6oI-6I), a Leicestershire nobleman who had married Brooke's sister and was closely associated with the Puritan opposition to Charles I. By the outbreak of Civil War Coppe thus appears to have begun to establish a reputation among Puritans in the Warwick area. Though lacking money and of humble social status, his godly background and natural abilities had enabled him to gain entry into stridently anti-Catholic, anti-Arminian and antiSocinian circles. Rising on the crest of Puritan patronage, he seemed destined to espouse these views as a prominent Presbyterian preacher.

\section{A 'most zealous Re-baptizer'}

On Friday, 7 June I644, Colonel William Purefoy (c.1580-1659), having participated in the Parliamentary relief of Gloucester, began his assault on Compton House, seat of the earl of Northampton and a major Royalist stronghold situated between Warwick and Banbury. An ally of Lord Brooke, an iconoclast and a patron of godly clergy in Warwickshire, Purefoy was to favour a strict Presbyterian church settlement and sign the death warrant of Charles I. Mustered at Warwick and Coventry his force consisted of 400 infantry and 300 cavalry supported by ordnance. After a fierce engagement in appalling weather the great Tudor mansion was pounded, falling on Sunday morning with several officers and I20 soldiers taken prisoner. Money, horses, sheep and cattle were plundered, the monuments in the church defaced and a Parliamentary garrison installed under the command of Major George Purefoy. It seems that by the time of the siege Coppe, perhaps through Dugard's influence, had been appointed minister to Major Purefoy's troop on a salary of $20 s$. a week. ${ }^{64}$ While stationed at Compton House, Coppe doubtless witnessed Purefoy's depredations as nearby communities were pressed into supplying labour, food, fodder and bedding for the garrison. He may also have been present on 30 January i 645 when a surprise early morning assault launched by about I,ooo Royalist troops was desperately repulsed by Purefoy. Intriguingly, Purefoy's account refers to 'Cobbs pound', perhaps a courtyard where Coppe preached. ${ }^{65}$ In February

63 Samuel Fisher, Baby-baptism meer babism, London 1653 (Wing F.ro55), 413.

${ }^{64} \mathrm{SP} 28 /{ }_{13} 6 \mathrm{pt} 37$, fo. 4v; Philip Tennant, Edgehill and beyond: the people's war in the South Midlands, ${ }_{1} 642-I 645$ (Banbury Historical Society, xxiii, I992), I6o-70.

${ }_{65}$ George Purefoy, A letter from Serjeant Major Purefoy governour of Compton House, London 1645 (Wing P.4228); Tennant, Edgehill and beyond, 205-7. 
I645 Coppe received an initial payment of $35 l$. for thirty-five weeks service. He was present at the muster of the garrison on 23 April I646, but may have left the army in June I646 when Parliament's troops were removed from Compton House. ${ }^{66}$

It was to be said of Coppe that for 'a long time' he 'pretended both to learning, reason and Religion' and that, according to credible information, he 'walked very strictly, til he first fell off from submitting to Church Government, after which he suddainly passed through all the forms now in fashion ... to holding ... Anabaptistical opinions,${ }^{67}$ Coppe himself recalled that he 'walked most zealously, and most conscientiously' in the way of adult baptism and that it 'did, and now doth, fing dirt in the face of all other waies - affirming all other - to be false waies [cf. Palm cxix. 128], and worships' ${ }^{68}$ He may have been rebaptised in the River Avon or perhaps by a water-mill. Significantly, there were reportedly Baptists among the garrison at Warwick Castle and at Coventry, where before July i644 Richard Baxter disputed with Benjamin Coxe (I595-I663?), 'an old Anabaptist Minister' sent from London of 'competent learning and parts'. ${ }^{69}$ Baxter, moreover, remembered that before the battle of Naseby (I4 June I645), when he was preacher to the garrison at Coventry and Coppe was preacher to the garrison at Compton House, 'I heard of no opinion that he vented or held, but, the Necessity of Re-baptizing, and Independency, and was a sharp Reproacher of the Ministry. ${ }^{, 70}$

This deprecating image of Coppe as a fiery, sectarian preacher is seemingly confirmed by apparent autobiographical allusions in Coppe's later prophetic writings. Recounting the spiritual tribulations of a young man 'void of understanding' (cf. Matt. xix. I6-22), Coppe describes his bewitchment by the whore of Babylon (Revelation xvii. 5), a flattering, deceitful figure that hunts after him, following him 'from street to street, from corner to corner, from grosse Protestantisme to Puritanisme, \&c. at length from crosse in baptisme, and Common-Prayer-Book to Presbyterianisme'. Accounting the sacrament of the lord's supper a vain form of religion, that is 'eating of a bit of bread, and drinking a sip of wine' perhaps once a month, the young man quickly passes to 'Independency, and from thence perhaps to Anabaptisme', ${ }^{71}$

Baxter reckoned that Coppe 'continued a most zealous Re-baptizer many years, and rebaptised more then any one man that ever I heard of in the

${ }_{66} \mathrm{SP} 28 / \mathrm{i} 36$ pt 37, fo. 4v; SP 28/123 pt 2, fo. 282; SP 28/184 (no piece number).

67 Philalethes [pseud.], An answer to Doctor Chamberlaines scandalous and false papers, London 1650 (Wing A.3357), 6. ${ }^{68}$ Coppe, Copp's return, sig. A2r-3.

69 Thomas Edwards, Gangraena, London I646 (Wing E.228, E.234, E.237), pt I, p. I49; Calendar of the correspondence of Richard Baxter, ed. N. Keeble and G. F. Nuttall, Oxford I99I, i. $4 \mathrm{O}-\mathrm{I}$; Richard Baxter, Plain Scripture proof of infants church-membership and baptism, London $\mathrm{I}_{5} \mathrm{I}$ (Wing B.1344), sig. b4v, and Reliquiae Baxterianiae, pt I, pp. 45-6.

70 Baxter, Plain Scripture proof, I48.

${ }^{71}$ Abiezer Coppe, A second fiery flying roule, London I649 (Wing C.6o87), I9-2I. 
Countrey, witnesse Warwickshire, Oxfordshire, part of Worcestershire, \& c. ' ${ }^{72}$ This may be an exaggeration, perhaps stemming from Coppe's alleged boast to some Oxford scholars that he had 'baptized seven thousand people' ${ }^{73}$ Yet he had been a 'leading man', claiming that he had 'shined gloriously in the eyes of many hundreds' who had lived with him in that region. ${ }^{74}$ Indeed, Coppe's standing within the Baptist churches was supported by his association with Hanserd Knollys (I598-I69I) and William Kiffin (I6I6-I70I).

In the autumn of 1646 Knollys and Kiffin travelled from London to Coventry, probably at the request of Baptists in the vicinity, to engage in debate on the validity of infant baptism with John Bryan, vicar of Holy Trinity, and Obadiah Grew (1607-89), vicar of St Michael. On the Sunday before the disputation the Baptists flocked in 'great numbers' to encourage their 'Champions', but apparently behaved so boisterously and rudely that the magistrates denied them the use of the town hall. An alternative public venue was found and thousands apparently attended. As one of the leading Baptists in the region and perhaps even pastor of a Baptist congregation in Coventry, ${ }^{75}$ Coppe acted as scribe to Knollys and Kiffin. The proceedings, however, were never published and the Baptists' silence eventually encouraged Bryan and Grew to claim victory. ${ }^{76}$

Coppe's association with Knollys and Kiffin makes it likely that he subscribed to the tenets declared in The confession of faith (printed by Matthew Simmons), which had been issued before i6 October i644 by seven churches in London, with a second edition (printed by Matthew Simmons and sold by John Hancock) distributed outside the House of Commons in January I646. ${ }^{77}$ Modelled on the Separatist Confession of 1596 and prompted by unfavourable comparisons with the 'odious errours' maintained by the Anabaptists of Münster more than a century before, The confession refuted allegations that Baptists believed in free will and the possibility of the elect falling away from grace, and that they denied original sin. Instead it affirmed that only the elect were to be saved by Christ's death, that 'those which have union with Christ, are justified from all their sinnes, past, present, and to come' by the blood of Christ, that all believers were a 'holy and sanctified' people, that believers were in continual warfare and opposition against sin

72 Baxter, Plain Scripture proof, i48.

73 Wood, Athenae oxonienses, iii, col. 96o.

74 Coppe, Copp's return, sig. A2r-3, p. I7.

75 Several Proceedings in Parliament xvi (I I-I8 Jan. I650), 213; The Man in the Moon xxxix (I6-23 January i650), 3iा.

${ }^{76}$ Nathaniel Stephens, A precept for the baptisme of infants, London I65I $_{5}$ (Wing S.545I), sig. A3r-v; John Ley, A discourse of disputations chiefly concerning matters of religion, London I658 (Wing L.1877), 7, 74-5.

${ }_{77}$ The confession of faith, of those Churches which are commonly (though falsly) called Anabaptists, London 1644 (Wing C.579o); A confession of faith of seven congregations or Churches of Christ in London, London 1646 (Wing C.5780); The writings of William Walwyn, ed. Jack McMichael and Barbara Taft, Athens, GA I989, I2I-2; Fournals of the House of Commons, iv. 420. 
and the Devil until Christ 'comes into his Kingdome', that baptism was to be dispensed only upon persons professing faith and that this was to be by plunging the whole body under water. Furthermore, although particular congregations constituted distinct bodies, they were nevertheless bound to observe the same rule and help one another 'in all needfull affaires of the Church'. ${ }^{78}$

The specific doctrines outlined in The confession suggest one source of influence on Coppe's spiritual journey. Another is the Calvinist Baptist milieu that he inhabited more generally, since Coppe's works contain suggestive parallels with his coreligionists' teachings. Hence in an epistle to Thomasine Pendarves (1618-fl.1672), published in Some sweet sips, of some spirituall wine (printed for Giles Calvert, I649), he declares:

For we are in that pure River of water of life, cleere as Christall [Rev. xxii.I], and that River in us, (which River you saw,) which is the Fountaine of life [Rev. xxi.6], the Living God, the River, the streames whereof make glad the City of God [Rev. iii.ı2; xxi.2].

We are (I say) in that River, and that River in us, when we are besides our selves, undone, nothing, and Christ all, in all [Colossians iii.II], in us.

The River is as cleare as Chrystall, nothing but Christ, all Christ, Chrystall - it is as clear as Chrystall, Christ-all, Halelujah. ${ }^{79}$

This resonates with Knollys's sermon on 'But Christ is all and in all' (Col. iii.I I), which Knollys had attempted to deliver at Debenham in Suffolk but was, by his own testimony, 'stoned out of the Pulpit': 'Christ is water of Life, a pure River of Living water cleer as Chrystall, flowes from this Fountain in the hearts of Believers, Revel.22.I.I7, Joh.7·37,38 and Joh.4.Io.I2,I4. ${ }^{80}$

Likewise, Coppe's epigraph to $A$ remonstrance echoes the title of a sermon preached by Captain Paul Hobson (d.I666) to the garrison at Newport Pagnell and in a house at Lathbury, Buckinghamshire, in June I645: 'Wisdome Justified of her Children' (Matt. xi. I9). ${ }^{81}$ For Hobson the Pharisees were so opposed to truth in their spirits that they could not recognise any form where Christ was present. Interpreting the verse as an 'affirmation of grace, brought forth in opposition to corrupt nature' he asserted the doctrine that 'the spirit of the world will not justifie but condemne Truth'. Though scorned and imprisoned for declaring the 'minde of God', Saints were comforted because 'Christ being one with the Deitie, is the naturall Sonne; we partaking of the Deitie by him, are adopted sons'

78 Confession of faith, no pagination.

79 Coppe, Some sweet sips, 54 .

80 Hanserd Knollys, Christ exalted, London I645 (Wing K.7o6), title-page, 3, and The life and death of that old disciple of Jesus Christ ... Mr. Hanserd Knollys, ed. William Kiffin, London I692 (Wing K.715), 22.

81 Original letters illustrative of English history, 3rd ser., ed. Sir Henry Ellis, London I846, iv. $265^{-6 .}$ 
(Galatians iv.5). ${ }^{82}$ Similarly, Coppe denounced 'All fleshly interests, carnal Gospellers, and pretenders to Religion', declaiming against their 'hypocrisie, pride, covetousness, self-seeking, and villany, covered under the cloak of fleshly holiness and Religion'. He laughed, 'having sweet union and communion with the Father and the Son; living in that Kingdom wherein dwelleth righteousness and peace'. Neither did he repent. ${ }^{83}$

Equally significant was Coppe's proclamation 'Sin and Transgression is finished and ended; and everlasting righteousnesse brought in' (Daniel ix.24) and his assertion that 'perfect freedome, and pure Libertinisme' served the 'Eternall God, who am UNIVERSALL Love'. ${ }^{84}$ In the preface to Tobias Crisp's posthumously published sermons Christ alone exalted (I643), Libertinism was defended as ' the preaching of the free Grace in Christ' ${ }^{85}$ Moreover, Crisp - a minister who was considered an Antinomian - used the text 'sin shall not have dominion over you: for ye are not under the law, but under grace' (Romans vi.I4) to maintain that 'when we come under grace by Christ' the dominion of the Law, or rather the dominion of sin, is 'captivated and subjected by Christ' so that 'we are discharged from the fault and guilt of sinne ${ }^{86}$ In the same vein Knollys, who had also been suspected of Antinomianism and was to be one of twelve Nonconformist ministers who confirmed the authenticity of Crisp's unpublished sermons on free grace, emphasised that 'the blood of Jesus Christ his Son, cleansed us from all sin' (I John i.7); though by this Knollys did not mean 'a perfect and totall freedome from all sin' but only freedom from the guilt and pollution of sin, for 'if we say that we have no sin, we deceive our selves' (I John i.8). ${ }^{87}$ These teachings may have provided the platform that enabled Coppe to reach higher towards 'a more excellent way [I Cor. xii.31], living and triumphing in joy unspeakable, and full of glory [I Peter i.8], in the power, spirit, and life' of that which he was groping after ' in the figure, flesh, form and outside' ${ }^{88}$

Coppe was also to revel in the impending day of judgement that he believed awaited the chastisers of 'the Lords Servants; (who come from a farr and strange countrey,) for they caught one, entreated him shamefully, sent him away empty, and shamefully handled him; at another they cast stones, and wounded him in the head: another they beate ... And another they killed, and so they would all, if they could, and the Heire too' ${ }^{89}$ Stoning was the Old Testament penalty prescribed for blasphemy (Leviticus xxiv.I6) and

${ }^{82}$ Paul Hobson, A garden inclosed, and wisdom justified only of her children, London I647 (Wing H.2274), 68-9, 73-4, 80. ${ }^{83}$ Coppe, Remonstrance, I-2.

84 Idem, Fiery flying roll, preface, p. I.

${ }^{85}$ Robert Lancaster, 'Preface to the reader', in Tobias Crisp, Christ alone exalted, London I643 (Wing C.6955).

${ }_{86}$ Hartlib papers, Sheffield University Library, HP 39/2/2A-B; Crisp, Christ alone exalted, i9.

87 Fournals of the House of Lords, iv. 494; Edwards, Gangraena, pt I, p. 97; Knollys, Christ exalted, $5^{-6 .}$

88 Coppe, Copp's return, sig. A2r-3.

${ }^{89}$ Idem, Some sweet sips, I7. 
Coppe's reworking here of a parable in the Gospels (Mark xii.I-9) recalls the punishment meted out to Knollys at Debenham as well as Kiffin at Tower Hill when he had emerged from attending a conventicle comprised of several congregations. ${ }^{90}$ Coppe, too, suffered at the hands of persecutors and was imprisoned in Coventry gaol for his 're-baptizing'. ${ }^{91}$ Such was the magnitude of his case that on 28 November ${ }^{6} 646$ the Governor and Committee at Coventry wrote to the House of Commons concerning him. ${ }^{92}$ Afterwards Coppe claimed that he 'sustained a I4 weeks close imprisonment' without 'bail or mainprize', suggesting that he was accused of felony. ${ }^{93}$ Coppe was probably fortunate to escape being branded in the left cheek with the 'letter B', which the Commons had debated in September as the penalty for blaspheming the name of God. ${ }^{94}$ His congregation probably paid his gaoler's fees as he abhorred both tithes and preaching for money. ${ }^{95}$

\section{The burning of the house of Jacob}

In his twenty-eighth year Coppe underwent a profound transformation, an experience that he came to represent as a spiritual passage from death to life. ${ }^{96}$ Reflecting upon his former sanctity, his 'prayers tears, sighs, groans, watchings, fastings, humiliations \& c.', Coppe recalled his 'self-seeking' in first observing and then scorning 'carnall' gospel ordinances. ${ }^{97}$ Hinting at the necessity of having a contrite, 'soft heart' (cf. Ezekiel xxxvi.26), Coppe recounted how 'God in his infinite wisdome' had laid low his vanity and levelled his pride - which is the 'true and pure levelling' ${ }^{98}$ Reading Obadiah's prophecy of the burning of the house of Jacob (Obadiah i.I8) as an allegory of the incendiary appearance of the Lord of hosts upon his 'fierce, rugged flesh', Coppe narrated how his 'hatred, strife, envy, malice, evil surmizing \& c.' was utterly consumed by the 'Celestiall Fire' of God's love:

First, all my strength, my forces were utterly routed, my house I dwelt in fired; my father and mother forsook me, the wife of my bosome loathed me, mine old name

${ }^{90}$ Remarkable passages in the life of William Kiffin, ed. William Orme, London $1823,14-15$; Middlesex county records, I625-I667, ed. John Jeaffreson, London I886-92, iii. I70; E[dward] $\mathrm{W}$ [histon], The life and death of Mr. Henry Jessey late preacher of the Gospel, London i67i (Wing W.I679), Io; cf. Jeremiah xii.Io; Matt. xxi.33-4I ; Luke xx.9-16.

91 Baxter, Plain Scripture proof, i48.

${ }_{92}$ Cf v. 34; cf. Coventry City Record Office, BA/H/C/17/2, fo. 58v.

93 Coppe, Copp's return, sig. A2r-3, and Second fiery flying roule, 20.

${ }^{94}$ Idem, Fiery flying roll, 7, and Second fiery flying roule, 20; C7 iv. 659; [Anon.], A vindication of a printed paper, London I646 (Wing V.465), sig. Br-v. $\quad 95$ Coppe, Second fiery flying roule, 5.

${ }^{96}$ Idem, Copp's return, 2, Io. $\quad{ }_{97}$ Ibid. 3; Second fiery flying roule, 21, 22.

98 Idem, 'An additional and preambular hint, - as a general epistle written by ABC', in Richard Coppin, Divine teachings, London I649 (Wing C.6og6), preface; Coppe, Copp's return, IO-II, and Second fiery flying roule, 22. 
was rotted [Proverbs x.7], perished; and I was utterly plagued, consumed, damned, rammed, and sunke into nothing, into the bowels of the still Eternity [cf. Is. lvii. I5] (my mothers wombe) out of which I came naked, and whereto I returned again naked [Job i.2I]. ${ }^{99}$

Coppe continued his reminiscences by relating how he lay a while 'rapt up in silence'. At length he heard with his 'outward care' a most 'terrible thunderclap, and after that a second' (cf. Rev. vi.I). Upon the second thunderclap 'I saw a great body of light, like the light of the Sun, and red as fire, in the forme of a drum (as it were) whereupon with exceeding trembling and amazement on the flesh, and with joy unspeakable [I Peter i.8] in the spirit, I clapt my hands [Psalm xlvii.I], and cryed out, Amen, Halelujah, Halelujah, Amen' (Rev. xix. 4). And so he lay 'trembling, sweating, and smoaking (for the space of half an houre)' (Rev. viii.I) before the immanent presence of the Lord. At length Coppe entreated the Lord: 'what wilt thou do with me; my most excellent majesty [Dan. iv.36] and eternall glory (in me) [cf. 2 Timothy ii.Io] answered \& sayd, Fear not, I will take thee up into mine everlasting Kingdom [Psalm clxv.I3]. But thou shalt (first) drink a bitter cup, a bitter cup, a bitter cup; whereupon (being filled with exceeding amazement) I was throwne into the belly of hell' (Jonah ii.2). Coppe remembered how 'the life was taken out of the body (for a season)'; it was as if 'a man with a great brush dipt in whiting, should with one stroke wipe out, or sweep off a picture upon a wall'. After a while 'breath and life was returned into the form againe', whereupon he beheld 'various streames of light (in the night) which appeared to the outward eye; and immediately I saw three hearts (or three appearances) in the form of hearts, of exceeding brightnesse; and immediately an innumerable company of hearts [cf. Heb. xii.22], filling each corner of the room where I was'. At this vision a 'most strong, glorious voyce uttered these words, The spirits of just men made perfect' (Heb. xii.23). Coppe drew these recollections to a close by professing that the 'visions and revelations of God' were 'stretched' out upon him and within him 'for the space of foure dayes and nights, without intermission'. ${ }^{100}$ Baxter, however, was of the contrary opinion: 'Its most certaine that Copp was in a long trance \& hath seene strange Satanicall delusions. ${ }^{, 101}$

Coppe emerged from these experiences as a resurrected man, with his old name rotted (Prov. x.7) and with a 'new name' upon him and within him (Rev. iii.I2). ${ }^{102}$ The 'day star' was risen in his heart (2 Pet. i.I9), and as his erotic coupling of 'love' and 'dove' suggests (Song Sol. v.2), Coppe imagined that the 'day of the Lord' was at hand (Is. xiii.6). ${ }^{103}$ Here was 'a great cry,

\footnotetext{
99 Coppe, 'Additional and preambular hint'; Some sweet sips, 'Contents'; and Fiery flying roll, 'preface'. ${ }^{100}$ Idem, Fiery flying roll, 'preface'.

101 Dr Williams's Library, ms Baxter, Treatises, III 67 fo. 302 r.

102 Coppe, Some sweet sips, I5-16, 22-3, 50, and Fiery flying roll, 'preface'.

103 Idem, Some sweet sips, I I, 47, 2.
} 
and at mid-night too; Behold, The Bridegroome commeth' (Matt. xxv.6). For God would come upon 'Siginoth' (Habakkuk iii I) unawares and 'give a bill of divorce' (cf. Mark x. 4) to all 'carnall, fleshly fellowships'. ${ }^{104}$ In the manner of the Revelation of Jesus Christ sent and signified by his angel unto his servant John (Rev. i.I), Coppe presented a powerful vision of the impending apocalypse:

behold, behold, he is now risen with a witnesse [cf. Rev. xi.3], to save Zion with vengeance, or to confound and plague all things into himself; who by his mighty Angell [Rev. X.I] is proclaiming (with a loud voyce) That Sin and Transgression is finished and ended; and everlasting righteousnesse brought in [Dan. ix.24]; and the everlasting Gospell preaching [Rev. xiv.6]; Which everlasting Gospell is brought in with most terrible earth-quakes [Rev. xvi.I8], and heaven-quakes, and with signes and wonders following. ${ }^{105}$

Similarly, Coppe reworked the story of the 'filthy blinde Sodomites' who failed to recognise two angels in their midst (Genesis xix.I I) into a prophecy that 'Sodome must be burnt, Lot must be saved [cf. 2 Pet. ii. 7], flesh must die \& be crucified, and the Spirit live and dwell in the Saints. "106 Warning his readers to 'be not forgetfull of entertaining Strangers, for some in so doing have entertained Angels unawares' (Heb. xiii.2), Coppe declared: 'There are Angels (now) come downe from Heaven, in the shapes and formes of men, who are full of the vengeance of the Lord; and are to poure out the plagues of God upon the Earth [Rev. xv.I], and to torment the Inhabitants thereof. ${ }^{107}$ Coppe claimed that he himself had been 'plagued and tormented beyond expression' and affirmed that he had 'rather behold one of these Angels pouring out the plagues of God, cursing; and teaching others to curse bitterly' (Judges v.23; Nehemiah xiii.25; Rev. x. 6). Adopting the mantle of an angel (in the form of a man) he inveighed against the hypocrisy of carnal religious observance, announcing: 'Well! To the pure all things are pure' (Titus i. I5). ${ }^{108}$

\section{Confounding 'things that ARE' or 'committing base lewd sins'?}

Supposing that he had been 'changed in a moment, in the twinkling of an eye, at the sound of the Trump' (I Cor. xv.52), Coppe reportedly set about enacting his new principles. It was to be said of him that though he had 'good abilities' and preached well - 'admirable good Oratory' - he fell into the 'fearfull' sin of thinking that he was 'above Ordinances' and that being a 'childe of God' he might do as he wished. He began to live very loosely, cursing and swearing, 'spreading blasphemies, and committing base lewd

104 Ibid. 2, I3. ${ }^{105}$ Idem, Fiery flying roll, 'preface'.

107 Idem, Some sweet sips, 37, and Fiery flying roll, 8.
106 Ibid. 8, and Some sweet sips, 37-8.

108 Idem, Fiery flying roll, 8. 
sins'. ${ }^{109}$ Baxter likewise charged Coppe with unnamed 'filthy lascivious practices', adding the caveat:

Would any Christian ever have believed that such a man should have any Followers? and that men and women professing the zealous fear of God, should ever be brought to place their Religion in revelling, roaring, drinking, whoring, open full-mouthed swearing ordinarily by the Wounds and Bloud of God, and the fearfullest Cursing that hath been heard, as if they were all possessed with Divels. ${ }^{110}$

Many of these allegations echo, and in some instances perhaps derive from, pronouncements in Coppe's writings. Coppe maintained that he had rather hear 'a mighty Angell (in man) swearing a full-mouth'd Oath' than listen to 'a zealous Presbyterian, Independent, or spirituall Notionist, pray, preach, or exercise'. For God had 'so cleared cursing, swearing' in some, that what was taken for swearing and cursing in them was 'more glorious' than praying and preaching in others. Hypocrites would be condemned to hell for swearing, while angels (in the form of men) could swear by the heart, blood and wounds of the 'Eternall God' in 'profound purity'. ${ }^{111}$ Likewise, he exclaimed 'it's meat and drink to an Angel [who knows none evill, no sin] to sweare a full mouth'd oath' (Rev. x.6). ${ }^{112}$ Suggestively, Thomas Bakewell's $A$ confutation of the Anabaptists ( 1644 ) reproved those Royalists who dared Jehovah to damn and sink them into the pit of hell. At the first battle of Newbury (20 September I643), many of them reportedly blasphemed God and cursed the king with their last breath. ${ }^{113}$ Such conduct may have prompted Charles I to issue a proclamation against swearing and cursing in April I644, which was followed by William Strode's sermon preached before the king at Oxford on 'let your Communication be yea yea, and nay nay' (Matt. v. 37). ${ }^{114}$ Coppe's language was equally shocking and challenging, yet was rooted in apocalyptic imagery and a distinctive interpretation of Scripture rather than bravado or impiety. Though he does not appear to have consciously adopted certain aspects of Cavalier behaviour, the parallel is nevertheless significant. For it facilitated the future transformation of a polemical stereotype: the roaring, licentious, cussing Royalist turned 'Ranter'. Moreover, what Coppe did was appealing. According to Baxter some of his followers were set in the stocks at Stratfordupon-Avon for their oaths, perhaps by the same justices of the peace who in March I647 had examined a Worcester man for allegedly saying that 'our Saviour Christ was a bastard \& our virgin Mary a whore' and the king both

109 Ibid., 'preface'; Several Proceedings in Parliament xvi (I I-18 Jan. I650), 213.

110 Baxter, Plain Scripture proof, i48. $\quad{ }^{111}$ Coppe, Fiery flying roll, 8-9.

112 Idem, Second fiery flying roule, I2.

113 Thomas Bakewell, A confutation of the Anabaptists, London 1644 (Wing B.530),

'To the reader'.

114 A proclamation for the further restraint of prophane swearing and cursing, 8 Apr. 1644 (Wing C.26r6); William Strode, A sermon concerning swearing, Oxford I644 (Wing S.5985). 
'a knave \& a foole'. Likewise, Baxter was informed that some Baptists around Southam and Compton had been brought into this 'fearfull state'. Some 'moderate hopefull Anabaptists' near him were even inclined to it. ${ }^{115}$

In a different tone Coppe noted that there was a time to 'eat, drink, and be merry' (Ecclesiastes viii. I5) 'in the Lord'. This was the time to partake of the spiritual feast: 'To the finest wheate-flower [cf. Rev. xviii.I3], and the pure bloud of the grape [Deuteronomy xxxii.r4); To the fatted calfe, ring, shoes, mirth, and Musicke, \& c. [Luke xv.22-3] which is the Lords Supper indeed' [cf. I Cor. xi.20] ${ }^{116}$ Again, Coppe used the words of 'S.Paul' to assert that the 'things that ARE' must be 'confounded by BASE things' (I Cor. i. 28). Indeed, Coppe likened the figure of 'nice, demure, barren' Michal [2 Samuel vi.23] to a type of precisian disapproval. Heeding David's 'unseemly carriage, by skipping, leaping, dancing, like one of the fools' (2 Sam. vi.r6), he proclaimed that he was without sin: 'What base things? Why Mical took David for a base fellow, and though he had chosen BASE things, in dancing shamelesly uncovered before handmaids [2 Sam. vi. 20].' ${ }^{117}$

The image of an uncovered David is significant in this context, for it partly anticipates the allegation that it was usual for Coppe to preach 'stark naked' by day and to lie drunk with a wench 'stark naked' at night. ${ }^{118}$ This association of nudity with sexual licence is familiar from hostile accounts of adult baptism rituals. Thus the Presbyterian heresiographer Thomas Edwards observed that it was no wonder that many turned rebaptisers 'to dip young maids and young women naked', adding that it was an inducement to adultery. ${ }^{119}$ Tainted by accusations that the Anabaptists of Münster held it lawful to have many wives, Baptists vindicated themselves from the charge that they believed in polygamy. Even so, the depiction of Coppe as an adulterer is significant, for Coppe delighted in citing the scriptural precedent of Hosea, 'who went in to a whore' (Hosea i.2). ${ }^{\mathbf{1 2 0}}$

Coppe's writings and actions would play a central role in the emergence of what many contemporaries perceived as a sect, variously termed the 'High Attainers', 'Mad Crew' or 'Ranters'. Several of the most articulate and prominent figures who would be associated with these labels had been Baptists. Yet they came to regard themselves as having reached a spiritual state beyond Baptism. This was apparent to their former coreligionists and other observers alike. Indeed, those who had been among their foremost supporters were often the quickest to repudiate them. United in their opposition to the Laudian Church, they had emerged together from the belly of Puritanism at the calling of the Long Parliament only to discover that they

\footnotetext{
115 Baxter, Plain Scripture proof, I48; Shakespeare Birthplace Trust, BRT 4/I/I, nos 29-32.

116 Coppe, Copp's return, sig. Bv, and Some sweet sips, 37, 46.

117 Idem, Second fiery flying roule, IO, II.

118 Wood, Athenae oxonienses, iii, col. 96o; cf. 2 Sam. xi. 4.

119 Edwards, Gangraena, pt 3, p. I89.

120 Coppe, Second fiery flying roule, 7.
} 
had embarked on different spiritual paths. Conferences, recriminations and splits followed as identities became fashioned by shifting polemical strategies. What remained was a pattern of fractured networks. When Coppe appeared in print with his distinctive use of syntax and tone he articulated his spiritual experiences and apocalyptic warnings in a unique style. Such qualities have helped to disguise the fact that his statements (both written and reported) derive from a millenarian milieu rooted in the doctrines of particular election, free grace and adult baptism. Though exclusive in nature this was a shared tradition and it explains why the later Coppe's often misunderstood inflammatory beliefs and provocative gestures did not long remain unique. 